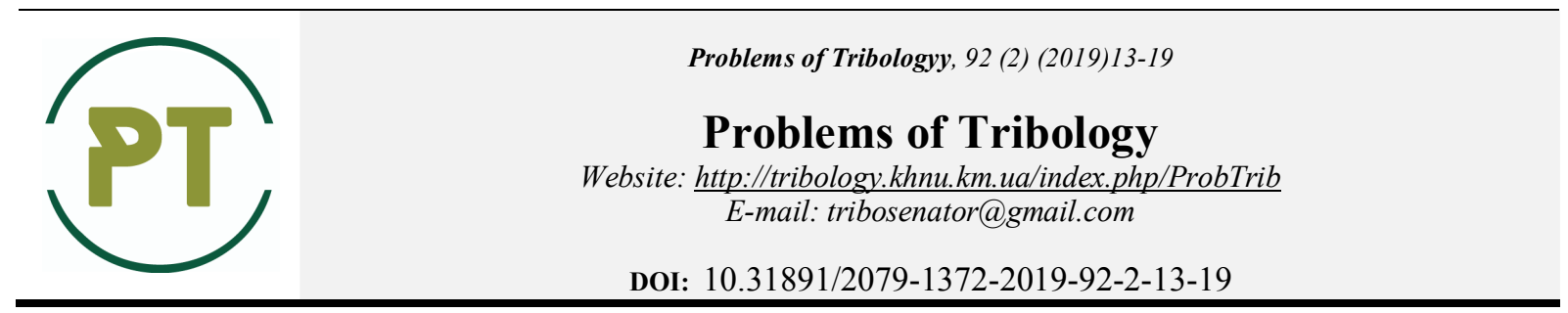

\title{
Contact problem of elastic strips with initial stresses with periodically placed resilient protective strap
}

\author{
V. Gonchar ${ }^{1 *}$, P. Kaplun ${ }^{1}$, O. Rudyk ${ }^{1}$, P. Matviishen ${ }^{1}$ \\ ${ }^{I}$ Khmelnitskiy National University, Khmelnitskiy, Ukraina \\ *E-mail: rogervova@gmail.com
}

\begin{abstract}
The article highlights the results of experimental research of the wear resistance of different structures of steels with different thermal and chemical-thermal treatment in corrosive and abrasive medium on special friction machines that modelled the working conditions of the extrudes when processing feed grain with the additives of saponite. Comparative study showed that metal wear resistance in corrosive and abrasive medium at higher temperatures depends not only on the hardness of friction surface, but also on its structure, phase composition and hardness of gradient change in the depth of the hardened layer. To provide extruder's high wear resistance when manufacturing feed grain mixed fodder with the additives of saponite it is recommended to make the details of extruding assembly unit of steel 5 that is strengthened by nitrohardening.
\end{abstract}

Key words: abrasive environment, wearproofness, nitrided layers, glow discharge.

\section{Introduction}

The enhancement of machine wear resistance and reliability is one of the most important tasks of mechanical engineering

The composition of saponite from Tashkiv deposit in Khmelnitski region

Table 1

\begin{tabular}{|c|c|c|c|c|}
\hline \multirow[b]{2}{*}{ Component } & \multirow{2}{*}{$\begin{array}{l}\text { Amount of } \\
\text { component } \\
\text { in rock, } \%\end{array}$} & \multirow{2}{*}{$\begin{array}{l}\text { Highly dispersed } \\
\text { fraction of saponite } \\
\text { rock }(<0.001 \mathrm{~mm}), \%\end{array}$} & \multicolumn{2}{|c|}{ Spectral analysis data } \\
\hline & & & element & $\begin{array}{c}\text { amount } \\
\text { of element }\end{array}$ \\
\hline $\mathrm{SiO}_{2}$ & $40.75-41.36$ & $40.47-43.08$ & $\mathrm{Sc}$ & $1.5-3.210^{-3}$ \\
\hline $\mathrm{TiO}_{2}$ & $1.29-1.50$ & $0.12-0.29$ & $\mathrm{Be}$ & $0.1 \quad 10^{3-}$ \\
\hline $\mathrm{Al}_{2} \mathrm{O}_{3}$ & $10.70-11.54$ & $11.56-13.06$ & Mo & $0.5-10^{-4}$ \\
\hline $\mathrm{Fe}_{2} \mathrm{O}_{3}$ & $14.81-15.76$ & $9.80-12.84$ & $\mathrm{~Pb}$ & $3.5-5.0 \quad 10^{-5}$ \\
\hline $\mathrm{MnO}$ & $0.12-0.19$ & $0.12-0.16$ & $\mathrm{Ga}$ & $6.3-12.0 \quad 10^{-5}$ \\
\hline $\mathrm{MgO}$ & $12.25-12.31$ & $12.39-13.28$ & $\mathrm{Nb}$ & $0,1 \quad 10^{-3}$ \\
\hline $\mathrm{CaO}$ & $1.41-2.40$ & $1.09-1.60$ & $\mathrm{Bi}$ & $2.510^{-2}$ \\
\hline $\mathrm{Na}_{2} \mathrm{O}$ & $0.07-0.26$ & $0.03-0.12$ & $\mathrm{Ba}$ & $1.5 \cdot 10^{-3}$ \\
\hline $\mathrm{K}_{2} \mathrm{O}$ & $0.43-0.60$ & $0.30-0.33$ & $\mathrm{La}$ & $2.5 \cdot 10^{-3}$ \\
\hline $\mathrm{P}_{2} \mathrm{O}_{5}$ & $0.07-0.09$ & $0.04-0.07$ & $\mathrm{Zn}$ & $4.7 \quad 10^{-3}$ \\
\hline $\mathrm{HO}_{2}^{+}$ & $10.40-10.95$ & $11.60-12.60$ & $\mathrm{Zr}$ & $1.2-2.010-^{2}$ \\
\hline $\mathrm{HO}_{2}^{-}$ & $4.80-5.66$ & $5.80-6.43$ & $\mathrm{Cr}$ & $0.5-0.8 \quad 10^{-2}$ \\
\hline & & & $\mathrm{Tl}$ & $2.0 \quad 10^{-5}$ \\
\hline & & & $\mathrm{Sn}$ & $1.5 \cdot 10^{-4}$ \\
\hline & & & $\mathrm{Li}$ & $2.0-3.310^{-4}$ \\
\hline & & & $\mathrm{Cu}$ & $4.0-8.0 \quad 10^{-3}$ \\
\hline & & & $\mathrm{Ag}$ & $2.0 \quad 10^{-3}$ \\
\hline & & & $\mathrm{Au}$ & $5.0-10.0 \quad 10^{-6}$ \\
\hline & & & Co & $0.5-4.0 \quad 10^{-3}$ \\
\hline & & & $\mathrm{V}$ & $1.5-3.210^{-3}$ \\
\hline & & & $\mathrm{Ge}$ & $0.12-0.15 \quad 10^{-3}$ \\
\hline & & & $\mathrm{Ni}$ & $1.5-3.0 \quad 10^{-3}$ \\
\hline
\end{tabular}


Machines and mechanisms in different industries operate in different conditions. Wear resistance of machine details is much influenced by the medium in which friction and wear occur. Baro-thermal processing of grains of different cultures with the addition of mineral saponite by extrusion method is a promising technology for manufacturing highly efficient fodder for livestock. After such processing high-molecular organic compounds in the grain become low-molecular ones that are easier digested by livestock organism. Digestibility of such fodder is $96 \%$. A small amount of mineral saponite (up to 5 percent of the total weight) in the fodder provides not only the significant (1.5 - 2 times) weight growth of livestock, but also increases quality of livestock products (meat and milk) and reduces sickness rate among young livestock. Mineral saponite contains more than 20 microelements useful for livestock (table 1).Operating experience of extruders for processing grain with saponite [2] showed that wear resistance and durability of heating cylinder parts are low. This is because mineral saponite contains quartz sand and is abrasive, and the moisture in the grain at $140-160{ }^{\circ} \mathrm{C}$ of barothermal processing creates an aggressive corrosive medium. The right choice of material, its thermal and chemical-thermal treatment has great influence on wear resistance and durability of extruder parts. Therefore, the enhancement of extruder's screw and cylinder wear resistance in such operating conditions is an important task.

\section{Experiment}

There were experimental studies of wear resistance of steels with different chemical composition (tab. 2), with different thermal and chemical-thermal treatment (hardening, carburizing, ion nitriding and nitrohardening) (tab. 3). Their aim was to study the influence of structure, hardness, of metastable phases presence in material structure and gradient diffusion coatings on wearing in corrosive and abrasive medium. Steel 1 carburizing (tab. 2) was carried out for 16 hours at $920^{\circ} \mathrm{C}$ with hardening in water at more than $800{ }^{\circ} \mathrm{C}$ and cooling for 2 hours at $150{ }^{\circ} \mathrm{C}$. Ion nitriding was done in oxygen fee saturating medium (a mixture of $75 \%$ $\mathrm{N}_{2}+25 \%$ Ar) at temperatures $570{ }^{\circ} \mathrm{C}$, the pressure in the vacuum chamber was $240 \mathrm{~Pa}$ for 6 hours. The technology of Steel 5 nitrohardening included ion nitriding with the following hardening at $105{ }^{\circ} \mathrm{C}$ to obtain a significant amount of metastable retained austenite in the structure of material.

Table 2

Chemical composition of steels under study

\begin{tabular}{|c|c|c|c|c|c|c|c|c|c|}
\hline \multirow{2}{*}{ № } & \multirow{2}{*}{ Steel grade } & \multicolumn{7}{|c|}{ Chemical composition, \% } \\
\cline { 3 - 9 } & & $\mathrm{C}$ & $\mathrm{Mn}$ & $\mathrm{Cr}$ & $\mathrm{Si}$ & $\mathrm{Ni}$ & $\mathrm{S}$ & $\mathrm{P}$ & $\mathrm{Cu}$ \\
\hline 1 & Steel 1 & 0.2 & 0.45 & $<0.25$ & 0.2 & $<0.25$ & $<0.04$ & $<0.04$ & $<0.25$ \\
\hline 2 & Steel 2 & 0.45 & 0.6 & $<0.25$ & 0.2 & $<0.25$ & $<0.04$ & $<0.035$ & $<0.25$ \\
\hline 3 & Steel 3 & 0.8 & 0.25 & $<0.2$ & 0.25 & $<0.25$ & $<0.028$ & $<0.03$ & $<0.25$ \\
\hline 4 & Steel 4 & 0.98 & 0.3 & 1,5 & 0.25 & $<0.3$ & $<0.02$ & $<0.027$ & $<0.25$ \\
\hline 5 & Steel 5 & 2.1 & 0.35 & 12 & 0.2 & $<0.35$ & $<0.03$ & $<0.03$ & $<0.3$ \\
\hline 6 & Steel 6 & 0.4 & 0.5 & 1.45 & 0.3 & $<0.3$ & $<0.025$ & $<0.025$ & $<0.3$ \\
\hline
\end{tabular}

The studies were carried out on a special device [3-5], which modeled the conditions of extruder's operating, at a pressure of $4 \mathrm{MPa}$, with sliding speed of $1.37 \mathrm{~m} / \mathrm{s}$ and at temperatures of $140^{\circ} \mathrm{C}$ in the model medium (aqueous solution of flour and saponite was in the ratio 8:9:1 respectively).

Table 3 shows the results of comparative experimental study of wear resistance of samples with different steels strengthened by different techniques.

Table 3

Wear and wear intensity of different steels in model solution at different friction way

\begin{tabular}{|c|c|c|c|c|c|c|c|c|c|c|}
\hline \multirow{4}{*}{ № } & \multirow{4}{*}{$\begin{array}{l}\text { Steel grade } \\
\text { and its treatment }\end{array}$} & \multirow{4}{*}{$\begin{array}{c}\text { Surface } \\
\text { hardness, } \\
\mathrm{MPa}\end{array}$} & \multicolumn{8}{|c|}{ Wear, $U$, micron; wear intensity $I \times 10^{-8}$} \\
\hline & & & \multicolumn{8}{|c|}{ friction way, $\mathrm{m}$} \\
\hline & & & \multicolumn{2}{|c|}{3000} & \multicolumn{2}{|c|}{6000} & \multicolumn{2}{|c|}{9000} & \multicolumn{2}{|c|}{12000} \\
\hline & & & $U$ & $I$ & $U$ & $I$ & $U$ & $I$ & $U$ & $I$ \\
\hline 1 & steel 1 & 2310 & 68 & 2.2 & 132 & 2.1 & 195 & 2.1 & 258 & 2.1 \\
\hline 2 & steel 2/ hardening & 5180 & 53 & 1.7 & 103 & 1.7 & 153 & 1.7 & 203 & 1.6 \\
\hline 3 & steel 3/ hardening & 6500 & 48 & 1.6 & 91 & 1.4 & 134 & 1.4 & 177 & 1.4 \\
\hline 4 & steel 4/ hardening & 6510 & 43 & 1.4 & 80 & 1.2 & 116 & 1.2 & 152 & $1 ., 2$ \\
\hline 5 & steel 5/ hardening & 6700 & 39 & 1.3 & 72 & 1.1 & 105 & 1.1 & 138 & 1.1 \\
\hline 6 & steel 6/ ion nitriding & 10050 & 25 & 0.8 & 43 & 0.6 & 63 & 0.7 & 88 & 0.8 \\
\hline 7 & steel $7 /$ ion nitriding & 5450 & 26 & 0.8 & 47 & 0.7 & 70 & 0.7 & 98 & 0.9 \\
\hline 8 & steel 8/ ion nitriding & 7860 & 24 & 0.8 & 43 & 0.6 & 64 & 0.7 & 90 & 0.8 \\
\hline 9 & steel 5/ ion nitriding & 8600 & 22 & 0.7 & 39 & 0.5 & 58 & 0.6 & 82 & 0.8 \\
\hline 10 & steel 1 /carburizing & 6950 & 28 & 0.9 & 52 & 0.8 & 78 & 0.8 & 108 & 1.4 \\
\hline 11 & steel 5/ nitrohardening & 8100 & 15 & 0.5 & 25 & 0.3 & 38 & 0.4 & 55 & 0.5 \\
\hline
\end{tabular}


Obtained data (tab. 3) were used for drawing graphs demonstrating the dependence of wear (fig. 2) of the studied samples on the friction way.

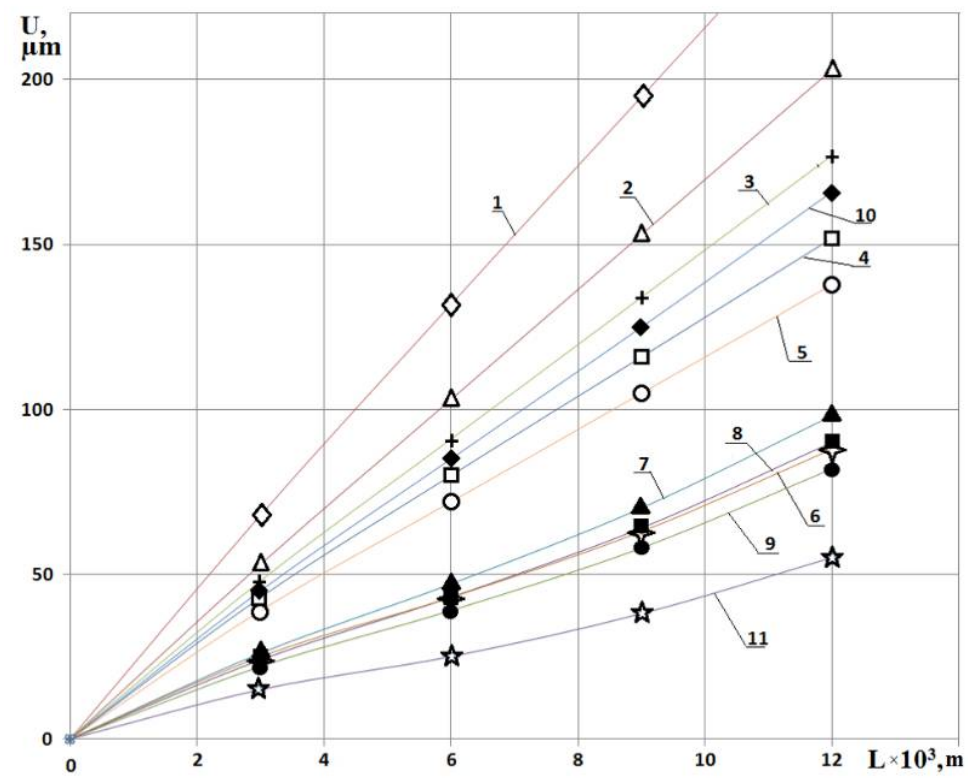

Fig. 1. The dependence of wear of different steel samples on friction way:

$$
1 \text { - steel 1; }
$$

2 - 5 - hardened steel (2- steel 2, 3 - steel 3, 4 - steel 4, 5 - steel 5);

6 - 9 - ion nitrided steel (6 - steel 6, 7 - steel 2,8 - steel 4, 9-steel 5);

10 - carburized steel 1 ;

11 - nitrohardened steel 5

Fig. 1 shows that all the samples in the initial period of wear undergo preaging of friction surfaces, which gradually reduced wear intensity. For steels with homogeneous properties in depth (steel 1, steel 2, steel 3, steel 4, steel 5) wear intensity stabilizes, and wear varies directly proportional to friction way. For nitrided steel (steel 6, steel 2, steel 4, steel 5) and carburized steel 20 having variable properties of the depth of the diffusion coating. Its wear does not change directly proportional to the way of friction.

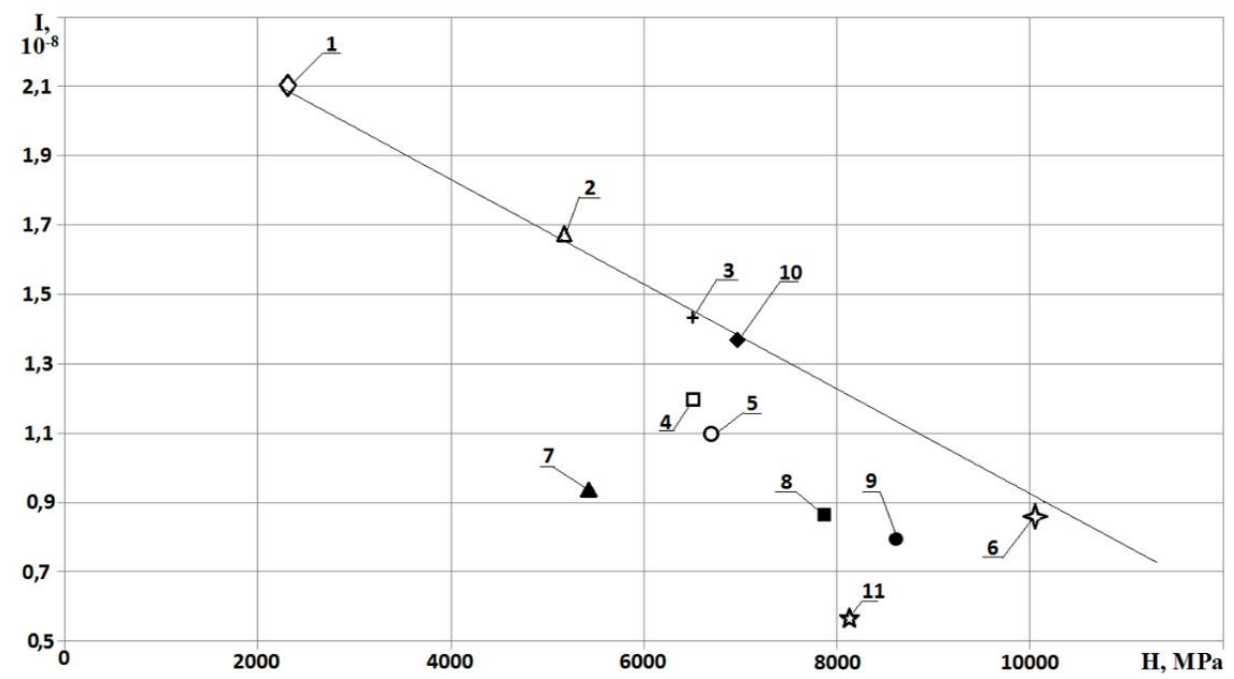

Fig. 2. Wear intensity of different steels in model medium after $12 \times 10^{3} \mathrm{~m}$ friction way:

$$
1 \text { - steel } 1 \text { without thermal tratment; }
$$

2 - 5 - hardened steels $(2$ - steel 2, 3 - steel 3, 4 - steel 5, 5 - steel 5);

6 - 9 - ion nitrided steels (6 - steel 6, 7 - steel 2,8 - steel 4, 9 - steel 5);

10 - carburized steel 1 ;

11 - nitrohardened steel 5

Fig. 2 shows wear intensity of different steels in the model medium after $12 \times 10^{3} \mathrm{~m}$ friction way. The figure shows that for non-alloy steel (steel 1, steel 2, steel 3) having homogeneous properties in depth, there is a linear inverse dependence of wear intensity on friction surface hardness, that is proved by studies of other 
authors $[6,10]$ for abrasive wear conditions. The presence of alloying elements in steels (steel 6, steel 4, steel 5) reduces wear intensity in abrasive wear [6 - 9]. Particularly large impact on wear intensity of steels has the quantitative content of chromium. Wear intensity reduces with the increase of chromium in steel, that is proved by wear of steels 4 and 5, in which the chromium content is 1.3 and $12 \%$ respectively. Among hardened steels steel 5 showed the lowest wear of wear (fig. 1, pos. 5). This is explained not only by a high content of chromium in the steel, but by the presence of more than $50 \%$ of retained austenite in the structure of the material, formed during its hardening at the temperature higher than $1050{ }^{\circ} \mathrm{C}$. Retained austenite during cyclic deformation in abrasive wear is transformed into martensite [9], thus absorbing part of activation energy in the process of friction, thereby increasing material wear resistance [11].

Table 4 shows the results of steel 5 property study (hardness, retained austenite and wear intensity) after hardening at different temperatures. Studies have shown that the hardness of the nitrided layer varies with the change of hardening temperature. The maximum hardness is achieved at $975{ }^{\circ} \mathrm{C}$ when its structure contains the maximum amount of martensite (44\%), 36\% of austenite and $20 \%$ of carbides. Decrease in hardness after hardening at temperatures below $975{ }^{\circ} \mathrm{C}$ is explained by the formation of soft ferrite component in the structure of material that is a part of troostite, which is characteristic for incomplete hardening of tool steels.

At a hardening temperature above $975^{\circ} \mathrm{C}$ hardness also decreases, and this is explained the increases of retained austenite in its structure. The increase of hardening temperature increases the alloying of solid solution by chromium and carbon as a result of carbide dissolution. As a result, steel has more retained austenite and less martensite. The hardness of steel is continuously decreasing and at hardening temperature above $1150{ }^{\circ} \mathrm{C}$ the structure of steel 5 contains $93 \%$ of retained austenite, $5 \%$ of carbides and $2 \%$ of martensite.

Table 4

Characteristics of steel 5 after hardening

\begin{tabular}{|c|c|c|c|c|c|}
\hline № & $\begin{array}{c}\text { Hardening } \\
\text { temperature } \\
T,{ }^{\circ} \mathrm{C}\end{array}$ & $\begin{array}{c}\text { Surface } \\
\text { microhardness } \\
\mathrm{H} 100, \mathrm{MPa}\end{array}$ & $\begin{array}{c}\text { Content of } \\
\text { retained } \\
\text { austenite A, \% }\end{array}$ & $\begin{array}{c}\text { Wear intensity } \\
I \times 10-8 \text { after } \\
\text { the way } 3 \times 103 \mathrm{~m}\end{array}$ & $\begin{array}{c}\text { Surface } \\
\text { microhardness } \\
\text { after friction } \\
\text { way } 3 \times 103 \mathrm{~m}\end{array}$ \\
\hline 1 & 900 & 6900 & 19 & 1.65 & 7000 \\
\hline 2 & 950 & 7090 & 28 & 1.37 & 7100 \\
\hline 3 & 1000 & 7040 & 40 & 1.15 & 7090 \\
\hline 4 & 1050 & 6700 & 55 & 1.1 & 6300 \\
\hline 5 & 1100 & 5900 & 72 & 1.65 & 4900 \\
\hline 6 & 1150 & 4800 & 93 & 2.6 & 6300 \\
\hline
\end{tabular}

The study of steel 5 wear resistance in model solution showed that minimum wear intensity $\left(1.1 \times 10^{-8}\right)$ is achieved at $1050{ }^{\circ} \mathrm{C}$ of hardening with approximately $55 \%$ of austenite, $21 \%$ of martensite and $14 \%$ of carbides. Wear intensity at $900{ }^{\circ} \mathrm{C}$ of hardening was $1.65 \times 10^{-8}$ that is 1.5 times higher than at hardening temperature of $1050{ }^{\circ} \mathrm{C}$. This happens because troostite structure contains ferrite and greater amount of martensite. Thus, the tendency of increasing steel wear resistance with the increased content of retained austenite in its structure and the decreased amount of martensite is observed.

The tendency of increasing steel 5 wear resistance structure with the increased amount of retained austenite and decreased amount of martensite in its structure at hardening temperature above $1050{ }^{\circ} \mathrm{C}$ is likely to continue if the stability of austenite remains constant. However, the raised hardening temperature simultaneously with the increased content of austenite decreases its sensitivity to phase $\gamma \rightarrow \alpha$ transformation in abrasive wear in the model solution. As a result, the value of surface strengthening is reduced and the total resistance to destruction in abrasive wear of steel 5 is reduced in comparison with the maximum value at a hardening temperature of $1050{ }^{\circ} \mathrm{C}$. Table 4 shows that wear intensity at $1150{ }^{\circ} \mathrm{C}$ of hardening was $2.6 \times 10^{-8}$ that is almost 2.5 times greater than at $1050{ }^{\circ} \mathrm{C}$.

The ability of a large amount of retained austenite to resist the destruction by abrasive wear shows deep internal changes occurring in the austenite. Plastic deformation by abrasive particles in wear process causes decomposition of metastable retained austenite into martensite. This increases the hardness of the friction surface. This is confirmed by X-ray studies [9] of steel wear with high content of retained austenite in which the original content of martensite increased from $20 \%$ to $60 \%$, and microhardness increased in 1.3 times.

Plastic deformation is accompanied by the slip of some layers of material. The slip as the result of plastic deformation is connected with the motion of a large number of dislocations on slip area and everything that obstructs their motion complicate the slipping. Therefore, the motion of dislocations in the structure of the material is obstructed by secondary phases, atoms of alloying elements, granule brims and even vacancies in the lattice. Pinning of dislocations generated during deformation of the material, maintains the hardened state in a material after removal of external loads. Therefore, the success of alloys hardening depends on effective obstruction to the motion of dislocations [12]. Metallographic studies [9] prove that in the process of abrasive wear the traces of plastic deformation can be observed at a considerable distance from the edge of the recess on 
the working surface, that is 10 microns on hardened and $30-40$ on non-hardened steels. The number of dislocations in very deformed layers reaches $24.1 \times 10^{12}$ per $\mathrm{cm}^{2}[13]$.

Thus, phase transformations, a large number of dislocations under the influence of plastic metal deformation on friction surface and, as a consequence, the significant slowdown and pinning of dislocations are the reason of increasing ability of steels with high content of retained austenite to resist to abrasive wear and increase of their wear resistance.

The results show that the samples strengthened by the technology of ion nitriding in plasma of glowing discharge in oxygen free medium had higher wear resistance compared to other technologies. It is clearly seen from fig. 1 where the curve lines $6-9$, which show that the magnitude and intensity of wear of steels under study after nitriding is almost 2 times lower when compared with their values after hardening. The highest wear resistance of friction pairs is achieved under optimal modes of ion nitriding of steels with regard to operating conditions.

It should be noted that most of metastable retained austenite that formed during the hardening of steel 5, decomposes in nitriding process due to the lower temperature of martensitic transformation $\left(<290{ }^{\circ} \mathrm{C}[9]\right)$ compared with nitriding temperature.

Nitrohardening provides pre-nitriding followed by hardeninig. It provides metastable retained austenite in the structure of the material. However due to the high temperature of hardening a part of nitrides on the surface splits and nitrogen diffuses into the depth of the nitrided layer, increasing its thickness (Fig. 3). This enhances steel wear resistance both due to retained austenite transformation under cyclic loading, and due to its alloying with nitrogen compared to traditional technology of nitriding (nitriding followed by hardening). From Fig. 1 one can see that the wear resistance of samples made of nitrohardened steel 5 is 1.5 times higher compared to nitrided steel and 3 times higher compared to hardened one.

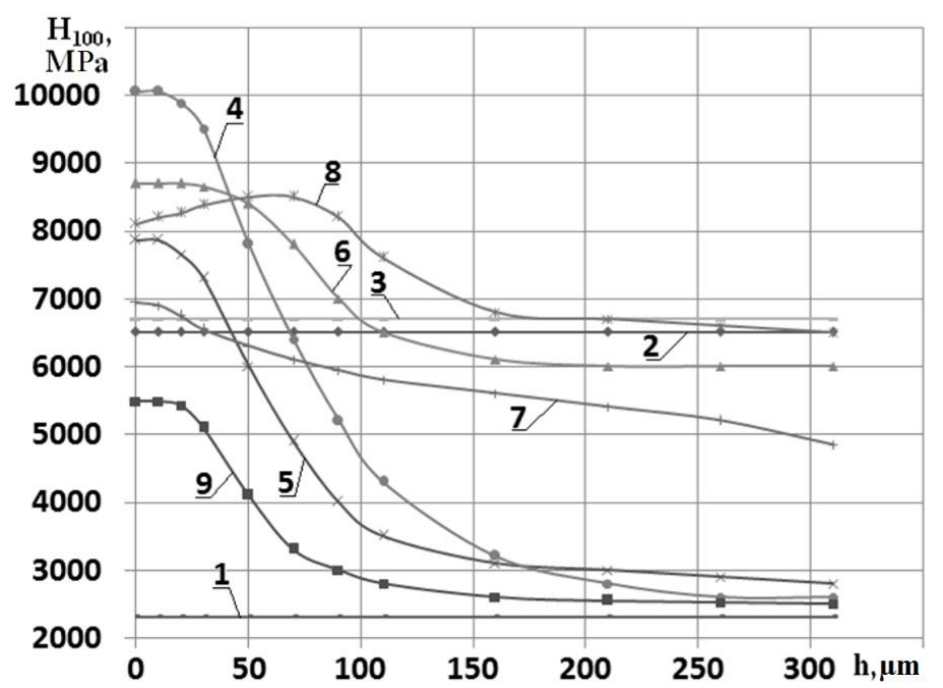

Fig. 3. Hardness distribution in the depth of surface layer at different thermal and chemical-thermal treatment: 1- steel 1;

2 - hardened steel 4;

3 - steel 5 hardened at tempetarure higher than $1050^{\circ} \mathrm{C}$;

4 - nitrided steel 6;

5 - nitrided steel 4;

6 - hardened steel 5 with the following nitriding;

7 - carburized steel 1 ;

8 - steel 5 nitrohardened at $1050{ }^{\circ} \mathrm{C}$;

9 - nitrided steel 2

Fig. 4 shows the results of experimental study of the properties of steel 5 after nitriding with previous hardening and nitrohardening (nitriding followed by hardening). The studies have shown that when nitriding steel 5 with previous hardening the surface microhardness gradually decreases with the increase of hardening temperature on linear dependence (fig. 4 straight line 3). This is caused by the increase of retained austenite in the structure after hardening. During nitriding retained austenite decomposes because of low temperature of its martensitic transformations (less than $290^{\circ} \mathrm{C}$ ) at temperature of nitriding and its content after nitriding does not exceed $10 \%$ (fig. 4 curve line 1). The structure of material is almost stabilized due to the small number of metastable phases. The intensity of surface wear increases with the increase of steel hardening temperature that is explained by the decrease in the hardness of material. 


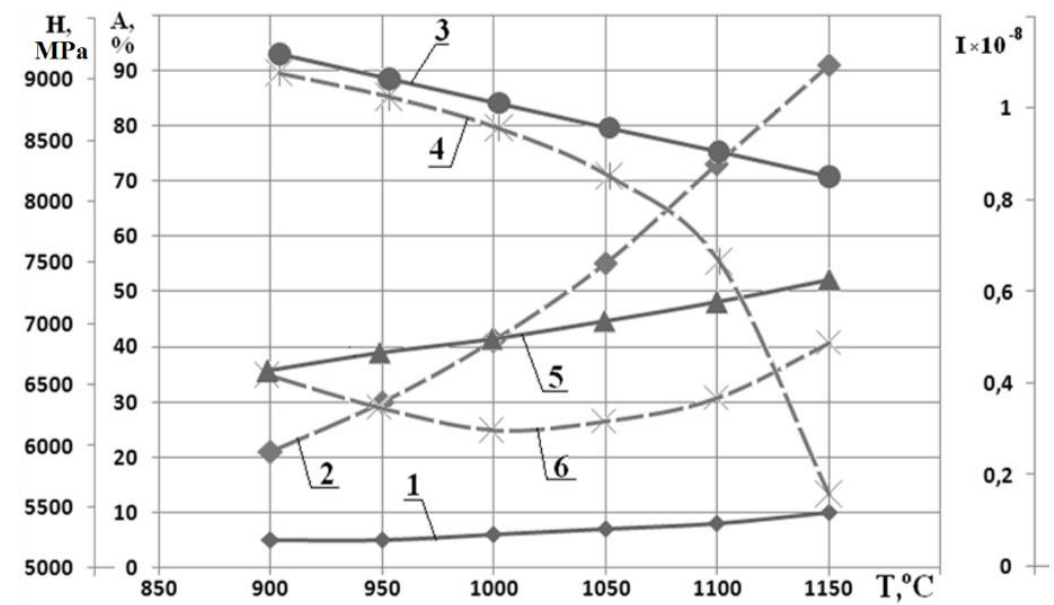

Fig. 4. Characteristics of steel 5 after nitriding (continuous line) and nitrohardening (dashed line):

1 - 2 - austenite content;

3 - 4 - microhardness of the surface layer;

5 - 6 - wear intensity after friction way $3 \times 10^{3} \mathrm{~m}$

At nitrohardening, unlike nitriding, hardening with the increase of temperature the content of retained austenite increases significantly and at $1150{ }^{\circ} \mathrm{C}$ of hardening it is $91 \%$. Maximum surface microhardness is $9050 \mathrm{MPa}$ at $900{ }^{\circ} \mathrm{C}$ of hardening, that is $150 \mathrm{MPa}$ lower than at nitriding. Surface microhardness decreases depending on the temperature of nitrohardening and on greater amount of austenite in the structure of material. The minimum hardness at nitrohardening is $5600 \mathrm{MPa}$, that is 1.5 times less than at nitriding. This is explained by a large amount of retained austenite, that has low hardness and a minimum amount of martensite.

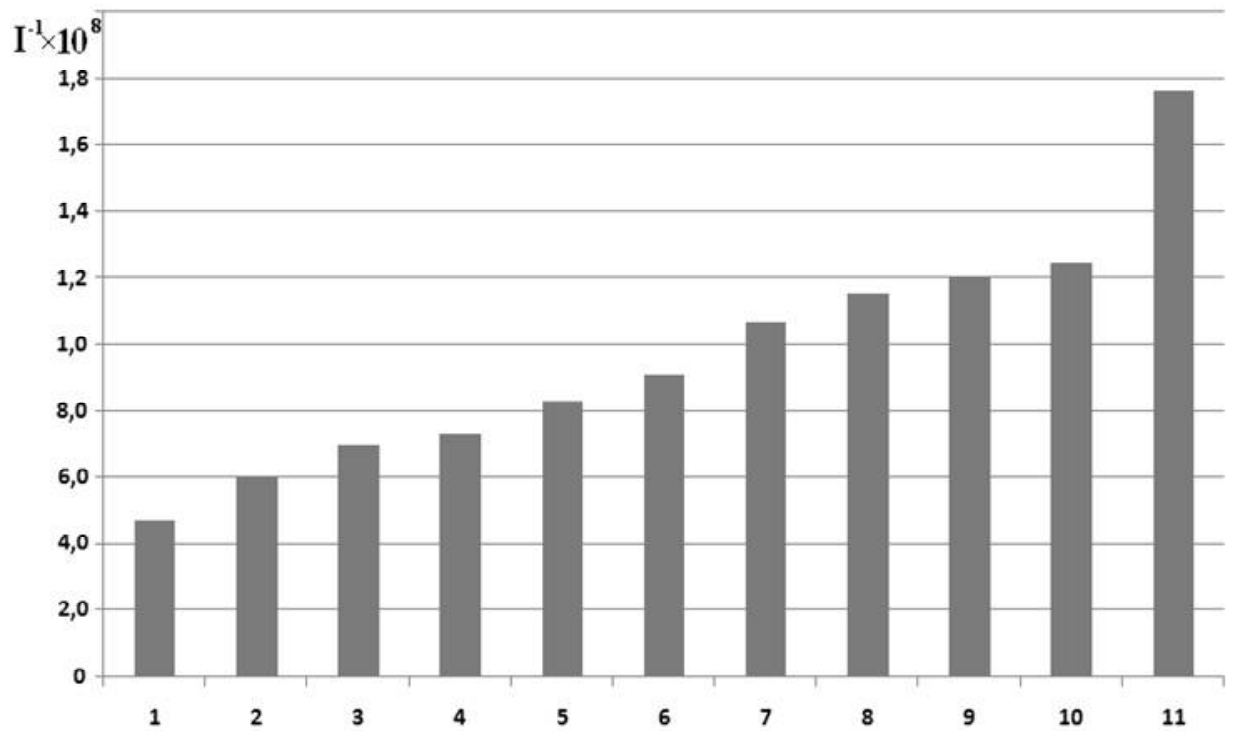

Fig. 5. Diagram of different steels wear at abrasive wear in model solutions with different thermal and chemical-thermal treatment: 1 - steel 1;

2 - steel 2 (hardening)

3 - steel 3 (hardening);

4 - steel 1 (carburizing);

5 - steel 4 (hardening);

6 - steel 5 (hardening);

7 - steel 2 (nitriding);

8 - steel 4 (nitriding);

9 - steel 6 (nitriding);

10 - steel 5 (nitriding);

11 - steel 5 (nitrohardening)

The increase of the minimum surface hardness at nitrohardening to $800 \mathrm{MPa}$ in comparison with the minimum hardness at hardening is explained by the content of oxide and nitride phases in the surface. Wear intensity at nitrohardening is much lower than at nitriding (fig. 4 curve lines 5, 6). Minimum wear intensity $(0.3$ $\times 10^{-8}$ ) is achieved at $1030-1050{ }^{\circ} \mathrm{C}$ of hardening and $45-55 \%$ of retained austenite, that is 1.5 times less when compared with nitrided and 3.7 times less when compared with hardened steel 5 . The regularity of influence of 
retained austenite on wear intensity of nitrohardened steel 5 is similar to the regularity of its wear during hardening, but differs in the fact that the velocity of wear intensity increase after hardening temperature of $1050{ }^{\circ} \mathrm{C}$ is lower because of alloying retained austenite by nitrogen that increases its stability.

Fig. 5 shows the diagram of wear resistance indicator $\left(I^{-1}\right)$ of various steels at abrasive wear in model solutions with different thermal and chemical-thermal treatment. The diagram shows that steel 5 has maximum wear resistance after nitrohardening, that is 3.7 times higher when compared with steel 20 without treatment, almost 2 - 3 times when compared with hardened steels, 2.4 times when compared with carburized steel 20 and 1.5 - 1.7 times when compared with nitrided steels.

\section{Conclusions}

Research has proved that in a corrosive and abrasive medium wear resistance of steels depends on hardness, chemical composition and structure of the surface layer. hardness;

1. For unalloyed steels with stable structure wear resistance is directly proportional to friction surface

2. For alloyed steels wear resistance increases as compared with unalloyed and increases with the increase of quantitative content of alloying elements such as chromium;

3. The presence of an optimal amount of retained austenite in the structure of material enhances wear resistance of friction surface;

4. Strengthening the steel surface by ion nitriding ensures high wear resistance;

5. the highest wear resistance of steels is achieved by nitrohardening (ion nitriding followed by hardening) at the optimal quantity of retained austenite in the structure of material.

\section{References}

1 Zasuha T.V. New disperse materials in livestock breeding. -Vinnitsa: Arbat, 1997. - 224p.

2 Kaplun V.G. Extruding of grain feedstock with saponite // V.G. Kaplun, V.S. Pavlov, N A. Mazur / Kombikorma №3. - 2001.- S24.

3. Gonchar V.A. Methods of study of extruder's screw wear resistance for processing feed grain with the additives of mineral saponite // Problems of Tribology, 2008.-№4 -P. 19-21.

4. Kaplun V.G. Study of wear resistance of friction pairs while processing feed grain with the additives of mineral saponite / V.G. Kaplun, V.A. Gonchar // Problems of Tribology, 2011.- №2 -P. 17-20.

5. Gonchar V.A. Comparative studies of wear resistance of samples with different properties in model abrasive medium / Problems of Tribology. - 2012, №2.-P. 38-41.

6. Tenenbaum M. M. Wear resistance of constructive material and machine parts at abrasive wear. - M., "Mashinostroenie", 1966. - $331 \mathrm{p}$.

7. Tkachev V.N. Wear and durability enhancement of farm machine parts $-2^{\text {nd }}$ ed., suppl. - M.: "Mashinostroenie", 1971. - 264 p.

8. Gladchenko A.N. Wear resistance of equipment for processing polymer material / A.N. Gladchenko, V.G. Zverlin, S.D. Petrenko, I.V. Shevelja. - M.: Mashinostroenie, 1992. - 256 p.

9. Popov V.S. Durability of equipment for fireproof manufacturing / V.S.Popov, N.N. Brikov, N.S. Dmitrichenko, P.G. Pristupa // "Metalurgija".-1978.-232 p.

10. Hrushhov M.M. Studies of metal wear resistance / M.M. Hrushhov, M.A. Babichev. - M.: USSR Academy of Sciences, 1960. - $352 \mathrm{p}$.

11. Kosteckij B. I. Friction, lubricant and wear in machines. -Kiev, "Tehnika", 1970. - 395 p.

12. Kittel' Ch. Introduction to solid-state physics. 2-nd ed.- M., "Fizmatgiz", 1963. - 696 p.

13. Chalmers B. Physical metallurgy. - M., "Metalurgizdat", 1963, 455p.

Гончар В.А., Каплун П.В., Рудык А.Е., Матвиишин П.В. Изучение износовой стойкости сталей в коррозионно-абразивной среде

Приведены результаты экспериментальных исследований износостойкости различных сталей с различной термической и химико-термической обработкой в коррозионно-абразивной среде на специальных машинах трения, моделировали условия работы экструдеров при переработке фуражного зерна с примесью минерала сапонита. Разработаны рекомендации для повышения износостойкости деталей которые работают в данных условиях.

Ключевые слова: износостойкость, азотированные слои, тлеющий разряд, абразивная среда 